\title{
Referral Hiring and Ethnically Homogeneous J obs: How Prevalent Is the Connection and for Whom?
}

\author{
James R. Elliott
}

Tulane University

Published online June 26, 2001

\begin{abstract}
Research on organizations and labor markets has rekindled interest in the role of insider referrals in matching workers to jobs, emphasizing the contribution this process makes to the reproduction of ethnic segregation in local labor markets. My objective in this study was to provide a systematic examination of ethnic/immigrant variation in these processes using unique data from the Multi-City Study of Urban Inequality. Three key findings emerged. First, evidence showed that insider referrals account for nearly all ethnic/ immigrant variation in informal job matching. Second, Latinos, especially newly arrived immigrants, are more likely than native-born Whites to enter jobs through insider referrals. Third, the correlation between insider referrals and ethnically homogeneous jobs is positive and significant only for native-born Blacks. These findings support the proposition that insider referrals are critical for understanding immigrant employment opportunities but also imply that Blacks are uniquely reliant on insider referrals to enter and thus sustain ethnically homogeneous jobs. () 2001 Academic Press
\end{abstract}

The hiring of new workers via employee referrals is presumed to be important for understanding ethnic divisions of labor because it creates a built-in bias toward incumbents: members of a particular ethnic group concentrate in particular jobs and when new employment opportunities become available at their workplace, they pass this information along to social contacts, often of the same race and ethnic background. In this manner many employment opportunities become detached from the open market, becoming rationed instead on the basis of insider referrals. Without such network hiring, one is left to assume, the matching of workers and jobs would be less constrained by ethnic identity, and ethnic divisions of labor would diminishthe (labor) market would erode ascriptive differences in the organization of work to the extent that human capital allows.

I thank Charlie Brody, Patricia Roos, Beth Rubin, and the anonymous reviewers for their feedback on earlier versions of this research.

Address correspondence and reprint requests to James R. Elliott, Department of Sociology, 220 Newcomb Hall, Tulane University, New Orleans, LA 70118. E-mail: jre@tulane.edu. Fax: (504) $865-5544$. 
This argument, while logical and widely held, suffers an important shortcoming: past studies have assumed, but not empirically demonstrated, that ethnically concentrated jobs tend disproportionately to be filled informally by employees who themselves work in these types of jobs and recruit friends, kin, and acquaintances to fill vacancies. Ethnographic studies of immigrant networks have come closest to filling this gap, providing detailed accounts of the resettlement and incorporation of foreign-born workers within local economies (Bodnar, Simon, and Weber, 1982; Boyd, 1989; Hagan, 1994, 1998; Hareven, 1975; MacDonald and MacDonald, 1964; Wells, 1996). However, we cannot be sure of the generality of these findings - case studies are better at developing theory and expectations than testing general theoretical propositions.

Survey analysis would help to address this shortcoming, but to date most relevant studies have lacked data on how workers and jobs are matchedinformal searches and hires are inferred rather than observed. Moreover, data constraints have encouraged researchers to focus on ethnic divisions of labor at the level of industries and occupations rather than at the level of jobs, that is, within workplaces (e.g., Glass, 1990; Logan, Alba, and McNulty, 1994; Model, 1997; Sorenson, 1989; Waldinger, 1996; Wilson, 2000). While attention to occupational and industrial niches continue to generate keen insights into the ethnic segmentation of local labor markets, a focus on jobs is essential for two basic reasons: (1) workers are matched to jobs, not industries and occupations; and (2) it is within jobs, not industries and occupations, that workers interact. So if race and ethnicity are salient dividers in the labor market, they should be especially so on the job.

In this paper I address these issues using unique and recently available data from the Multi-City Survey of Urban Inequality to investigate group differences in referral hiring and ethnically homogeneous jobs. The central questions are straightforward. Which groups are most likely to be matched to jobs through insider referrals? Which groups are most likely to enter ethnically homogeneous jobs? And to what extent are the two processes correlated? In answering these questions, I focus on five categories of workers: native-born Whites, native-born Blacks, native-born Latinos, and recent and established Latino immigrants, who are distinguished by whether they have lived in the United States 5 or more years. My goal, in addition to testing the empirical link between referral hiring and ethnically homogeneous jobs, is to assess whether this link is more important for immigrants than native-born minorities. I discuss the rationale for this focus below.

\section{BACKGROUND}

One of the more perplexing puzzles of contemporary urban labor markets is how the same restructuring processes that devastated job prospects for less educated Blacks during the 1980s and 1990s could absorb thousands of new immigrant workers, many of whom possess little formal education and, like 
Blacks, live in highly segregated inner-city neighborhoods. As scholars have engaged this question, the central problematic of contemporary urban inequality has shifted. The key question is no longer strictly one of job supply but also one of job distribution-who gets which jobs and why.

Increasingly answers to the distribution question focus on the salience of social networks for finding employment (Aponte, 1996; Cohn and Fossett, 1996; Elliott, 1999, 2000; Kasinitz and Rosenberg, 1996; Sassen, 1995; Waldinger, 1997). Instead of emphasizing well-documented declines in blue-collar jobs, a social network approach highlights the functions that personal contacts play in the labor market. These functions are essentially twofold. At the most basic level, contacts can provide job seekers with timely information about employment opportunities that may not be widely or publically known. Second, contacts can refer, or sponsor, job seekers, thereby improving their odds of acquiring particular positions. This second function is especially relevant in cases in which the contact is already working for the prospective employer.

While reasons a job seeker might benefit from an insider referral are fairly straightforward, reasons employers might favor insider referrals are less so. The accepted explanation is that referral hiring allows employers to "leverage" employees' social ties to their own advantage. Fernandez and colleagues (2000) distinguish five mechanisms through which this advantage can accrue. First, incumbent referrals can expand the pool of job applicants to include individuals who might not otherwise know about and apply for respective job openings (Breaugh and Mann, 1984; Fernandez and Weinberg, 1997; Schwab, 1982). Second, because referral ties tend to be homophilous (Myers and Shultz, 1951; Rees and Shultz, 1970; Ullman, 1966; see also Granovetter, 1995), and because incumbent referrers cleared a prior screening process, referred applicants are likely to be better qualified than nonreferred applicants. The third mechanism is "reputation protection": to the degree that employees think their reputations at work will be affected by the quality of their referrals, they will refer only qualified applicants (Rees, 1966; Rees and Shultz, 1970; Saloner, 1985; Ullman, 1966). Fernandez and colleagues (2000) refer to these three mechanisms collectively as the "richer pool" argument-employers benefit from insider referrals because they produce more and better applicants from which to choose.

The fourth mechanism by which referral hiring can benefit employers is through "information advantage" - the referrer passes along information to the employer about applicant qualities not easily assessed in formal recruitment procedures (e.g., work ethic and collegiality), while on the applicant's side, the referrer provides "extra" information about the job in question (e.g., informal rules and relations governing expectations and performance). The result is presumed to be a "better match" between the job and the eventual hire. Finally, referral hiring can benefit employers even after the job is filled. The argument is that the insider referrer is likely to help the newcomer in the organizational socialization process and perhaps even with on-the-job training, thereby boosting 
productivity and enriching the nascent bond between employer and newly hired worker (Grieco, 1987; Reichers, 1987; Sutton and Louis, 1987).

The overriding point behind all five mechanisms of referral hiring is that organizations, as well as workers, have incentives to match workers to jobs through insider referrals. These incentives help to explain why, in the recent National Organizations Study, 37\% of representatively sampled employers reported frequently using employee referrals to recruit new workers (Kalleberg, Knoke, Marsden, and Spaeth, 1996, p. 138). These incentives, however, cannot tell us if particular types of workers are more likely than others to gain employment through insider referrals. This gap is important because one of the presumed effects of referrer-referral homophily is to reproduce the demographic composition of the incumbent workforce. This situation occurs because social networks tend to be racially homogeneous, which means that there is a high probability that same-race candidates will be referred and hired through incumbent networks (Braddock and McPartland, 1987; Clark, 1964; Corcoran, Datcher, and Duncan, 1980; Model, 1993; Rees, 1966).

While this argument makes sense in theory, no study to date has explicitly examined racial and ethnic differences in referral hiring and its links to ethnically homogeneous jobs. Relevant studies instead have focused on racial and ethnic differences in workers' use of job contacts in general, regardless of whether these contacts worked for prospective employers. The general conclusion of these studies is that Latinos are significantly more likely than other major racial and ethnic groups to use their social networks to acquire jobs (Elliott, 1999; Falcon and Melendez, 1996; Green, Tigges, and Diaz, 1999; Mier and Giloth, 1985). Blacks, by contrast, are more likely than other racial and ethnic groups, including Whites, to rely on formal methods of job matching, such as answering classified ads, using public and private employment agencies, and simply walking in and applying for jobs (Green, Tigges, and Diaz, 1999; Holzer, 1987; Marx and Leicht, 1992).

Reasons for these racial and ethnic differences in informal job matching remain unclear. However, one theory suggests that they arise because informal job matching permits race to play a more prominent role in the hiring process than it does when formal channels are involved, and this fact hurts Blacks the most (Holzer, 1987, 1996). The corollary is that Blacks are more likely to acquire jobs through formal channels-not personal contacts-because formal channels provide more explicit criteria by which employers can evaluate applicants, thereby downplaying the effects of racial discrimination on the part of employers. This perspective receives prima facie support from recent case studies of employer recruitment practices. In their study of Chicago businesses, for example, Kirschenman and Neckerman (1991) found that White and Latino applicants are heavily favored over Blacks in the hiring queue. Waldinger (1997) reports similar findings from interviews with service and light manufacturing firms in Los Angeles, as do Moss and Tilly (1996) in their study of public and private employers in Los Angeles and Detroit. 
Another explanation for why Blacks are less likely than other ethnic minorities to find jobs through personal contacts is that fewer of them are foreign-born-a possibility largely ignored in recent quantitative studies of racial and ethnic differences in job matching (Elliott, 1999; Green, Tigges, and Diaz, 1999; Holzer, 1987). Immigrant status is crucial for understanding group differences in informal job matching for a couple of reasons. First, foreign-born workers tend to possess poor English skills and little education compared with native-born workers. These attributes combine with ethnic prejudices in United States society and a lack of experience with domestic labor markets to limit competitiveness for formal job openings, thereby rendering contacts especially important for gaining employment. Second, immigrants rely heavily on social networks in the relocation process, using them to find housing, a sense of community, and, perhaps most importantly, jobs at their point of destination (Hagan, 1998; Massey, Alcaron, Durand, and Gonzalez, 1987; Portes and Bach, 1985).

At the aggregate level, the unique salience of social networks among immigrants helps to explain why local unemployment rates have no effect on the likelihood of foreign-born workers settling in an area, whereas they have a strong, negative effect on native-born workers' propensity to do so (Sassen, 1995, p. 91). It also helps to explain how foreign-born workers can make surprising inroads into declining sectors of many urban economies, such as light manufacturing in New York and Los Angeles (Sassen, 1995, p. 91; see also Waldinger, 1996, 1997). An important implication for the present study is not just that immigrant workers are likely to rely especially heavily on personal contacts-particularly insider referrers - to find jobs, but also that after controlling for this fact, native-born Latinos and Blacks may have much more similar rates of informal job matching than prior research suggests.

Of course even if immigrants are more likely to acquire jobs through personal contacts than native-born minorities, this pattern does not necessary last forever. Indeed, Bailey and Waldinger (1991) argue that ethnically concentrated jobs- to which informal job matching is often presumed to lead-operate as a kind of "training system" in which newly arrived immigrants gain work experience, develop skills, and become more knowledgeable about how the local labor market works. As this experience accrues, foreign-born workers decrease their reliance on insider referrals and increase their competitiveness for jobs in the "mainstream" (i.e., predominantly White and formal) economy (Nee, Sanders, and Sernau, 1994).

To the extent these processes exert themselves, they have important implications not only for individual workers but also for ethnic divisions of labor within local labor markets. This is because, as mentioned before, informal job matching, in general, and insider referrals, in particular, are widely assumed to contribute to a process of homosocial reproduction-incumbents refer people like themselves, thereby reproducing their own sociodemographic characteristics on the job. 


\section{Recapitulation and Formal Hypotheses}

Drawing on the foregoing discussion, I posit the following hypotheses for empirical investigation.

Hypothesis 1. Insider referrals account for a significant share of all informal job matches.

Hypothesis 2. The likelihood of insider referrals varies by immigrant status, with newer arrivals being more likely than established immigrants and nativeborn minorities to acquire jobs through this type of informal matching.

Hypothesis 3. Workers who acquire jobs through insider referrals are more likely than workers who acquire jobs through other channels to enter, and thus reproduce, ethnically homogeneous jobs.

I discuss the data and measures used to examine these hypotheses below.

\section{DATA AND MEASURES}

Data for the present study come primarily from the Multi-City Survey of Urban Inequality (MCSUI), which is a multistage stratified random sample of adults living in Atlanta, Boston, Detroit, and Los Angeles during 1992-1994. I exclude Detroit from the present study because questions about job matching and composition went unasked in this portion of the survey.

In stage one of the sampling design, census tracts were stratified by race/ ethnicity and poverty status in each metro area. In Atlanta these census tracts were drawn from all nine counties of the 1990 Atlanta metropolitan area (Clayton, Cobb, DeKalb, Douglas, Fayette, Fulton, Gwinnett, Henry, and Rockdale). In Boston, census tracts were drawn from the entire Boston-LawrenceSalem Consolidated Metropolitan Statistical Area. In Los Angeles, they were drawn from the core county of the Los Angeles metro area, Los Angeles County, which is ethnically and economically diverse. In stage two, households were randomly selected from within these stratified census tracts. Face-to-face interviews were then conducted with individuals from the selected households. These interviews lasted approximately $2 \mathrm{~h}$, with the race/ethnicity of respondents and interviewers matched to minimize well-known race-of-interviewer effects (for more details about the MCSUI see Johnson, Oliver, and Bobo, 1994; O'Connor, Tilly, and Bobo, 2000).

The MCSUI's oversampling of individuals from minority and poor neighborhoods may bias the sample against relatively more successful immigrants who migrated out of the sampling frame into more "mainstream"suburban neighborhoods. If we assume that residence in such neighborhoods brings with it a convergence in labor market behavior with native-born workers, it would suggest that the results I report here overstate differences between immigrants and native-born workers because they focus on the experiences of relatively less successful immigrants. While this possibility cannot be dismissed, two factors minimize its potential influence. First, only the Los Angeles portion of the survey draws from a circumscribed portion of the target metro area, and this portion is 
hardly small or economically homogeneous. Second, the oversample of nonpoor, as well as poor, ethnic neighborhoods helps to ensure a balance between relatively successful and unsuccessful immigrants.

To ensure samples large enough for multivariate analysis, I pool the data from Atlanta, Boston, and Los Angeles. Included in the sample are native-born Whites, native-born Blacks, native-born Latinos, and immigrant Latinos. Immigrant Latinos I subdivide into two groups: "recent immigrants," who first entered the United States less than 5 years prior to the survey, and "established immigrants," who first entered the United States 5 or more years prior to the survey. Length of time in the United States is measured by the following question: "When did you first come to live in the (mainland) United States?" Values range from less than a year to 46 years, with a mean of 12.5 and a standard deviation of 8.1. The 5-year cut point is convenient but arbitrary; a shorter period would reduce the subsample of "recent" immigrants below 100 .

Because interest lies with job matching, I restrict the sample to non-selfemployed workers, ages 21 to 64, who entered new civilian jobs within 5 years of the survey date-an approach that results in 2030 recent job entrants. Subsample sizes for respective ethnic/immigrant groups appear in the top row of Table 1 and range from 122 for recent Latino immigrants to 707 for native-born Blacks. The 5-year restriction on job matching is a function of the survey instrument, which sought to increase reliability by limiting the historical period of recall-a common approach in surveys of job matching. Compared with this sample of recent job seekers, one might expect a more general sample to be older and perhaps less adventurous, since job tenure usually increases with age and because job switching often involves the pursuit of new opportunities (Granovetter, 1974). I discuss the measurement of key variables below.

\section{Job Matching}

In this study I identify three mutually exclusive types of job matching: (1) the use of formal channels; (2) the use of insider referrals; and (3) the use of other types of informal channels, including nonsearch matches. Information for all three types of job matching come largely from the following question: "Did you find your (last/present) job through friends or relatives, other people, newspaper ads, or some other way?" Formal matches refer to cases in which individuals actively searched for and acquired jobs through newspaper ads and "other" formal channels, such as help-wanted signs, state employment agencies, school placement offices, and private employment services. These "other" modes of formal job matching are inferred from related questions regarding respondents' job search activities, that is, how they looked for jobs prior to acquiring them.

If a respondent reports looking for and acquiring a job through a personal contact, the MCSUI asks about the characteristics of the contact, including whether he or she worked with the respondent's eventual employer. If the contact worked for the employer, the job match is considered the result of an insider 
referral; if the contact did not work for the respondent's eventual employer, the job match is defined as an "other," more generic, type of informal match. For both types of informal matching-insider referral and other-answers to related questions are used to exclude cases in which personal contacts merely provided verbal or written references; these cases are considered formal matches.

Included in the "other" type of informal job match are also respondents who acquired jobs without actively looking for them. Such nonsearch matches are inferred on the basis of two questions: "When did you last look for work?" and "How long have you been working for your present employer?" If the respondent reports being with his or her current employer for fewer than 5 years and reports last looking for work more than 5 years ago, the job match is assumed to have occurred without an active search. Because no job search questions were asked of individuals who last searched for work over 5 years ago, no additional information is available on whether the (inferred) nonsearch match occurred primarily through formal or informal channels. The logic behind including nonsearch matches as a form of informal job matching is that jobs that "fall into your lap" are unlikely to do so without help from others (Granovetter, 1995). So failure to include this type of job match would create a selection bias against informal job matching.

\section{Ethnically Homogeneous Jobs}

In this study I focus on ethnic divisions of labor at the level of the job, that is, according to particular tasks performed within particular workplaces. The joblevel measure is based on the question "What is the race and ethnicity of most of the employees doing the kind of work you do at the place where you work?" If the respondent reports that most co-workers are of the same racial and ethnic background, the job is considered an ethnically homogeneous job. If the respondent reports that no group comprises a majority or that the majority is a different race or ethnicity, the job is considered a nonhomogeneous job. For all groups, including recent and established immigrants, the race and ethnicity of co-workers is coded in broad terms-White, Black, Latino, Asian, or other-reflecting available categories in the MCSUI.

The validity of this job-based measure rests on the fact that it is at the level of the job, rather than at some abstract level like occupation or industry, that the matching of workers and jobs occurs. This face validity is further supported if the dichotomous indicator for ethnically homogeneous jobs is positively and significantly correlated with known measures of ethnic economic concentration, which it is. The simple correlation between the job-based measure used in this research and the local percentage of coethnics working in a given occupational grouping (discussed below) is .35, which is statistically significant at the .0001 level. Also, a simple $\chi^{2}$ test between the job-based measure and a dichotomous measure of 
employment in a local ethnic "industrial niche" (1, yes; 0 , no) is 22.5 , with $1 d f$, which is also statistically significant at the .0001 level. ${ }^{1}$

The reliability of the job measure hinges on two factors: (1) how broadly respondents construe "doing the same kind of work" they do and (2) how accurate their assessment of group composition is. When a person works in a job with 10 incumbents, estimates of group composition are likely to be highly accurate. However, when a person works in a job with 100-200 incumbents, which is common in some manufacturing jobs, estimates of group composition are likely to be less accurate. Because the MCSUI does not include information about the number of co-workers in each respondent's self-defined "job," I must treat both situations as qualitatively the same. While this situation is less than ideal, two considerations give us confidence in the reliability of the measure of homogeneous jobs used in this research.

First, respondents were asked to give a categorical assessment of group composition - a simple majority rather than an actual percentage. Given that very few jobs are racially balanced (Tomaskovic-Devey, 1993), this assessment should be relatively easy to make accurately and reliably - two people in the same work group are highly likely to provide the same answer. The second consideration comes from prior research on job composition measures. In his analysis of the North Carolina Employment and Health Survey (NCEHS), Tomaskovic-Devey (1993) compared racial composition measures derived at the occupational level from the Current Population Survey with those derived from job-based questions in the NCEHS regarding the self-reported percentage of non-Whites in each respondent's job. In the end he concluded that the two sets of estimates were "nearly identical" and that, "This should be a reassuring finding for readers who [are] skeptical whether survey respondents [can] provide information on the ... racial composition of their jobs" (1993, p. 176).

\footnotetext{
${ }^{1}$ Industrial niches have become a common way of operationalizing ethnic divisions of labor in metro labor markets. The accepted approach is to use data from public use samples of the population census to subdivide metro economies into 48 industrial sectors (see Logan, Alba, and McNulty, 1994). If the odds that an ethnic group is represented in a local industrial sector are 1.5 times greater than the odds we would expect based on the group's share of the local labor force, then the industrial sector is considered an ethnic niche for the respective group in that city. For example, if Latinos comprise one third of Los Angeles's metro labor force, then a local industrial sector is considered a Latino "industrial niche" if group members comprise $43 \%$ or more of the sector's workforce $(.43 / .57) /(.33 / .67)=1.53$. The odds ratio, rather than a simple percentage, is used to help control for the fact that smaller groups are more easily overrepresented. To further assess the face validity of my measure of homogeneous jobs, I calculated an industrial niche variable like that discussed above, using data from the 1990 5-Percent Public Use Micro Samples (PUMS) for each metro area-Atlanta, Boston, and Los Angeles. The dichotomous variable was then merged with the MCSUI data set, and a $\chi^{2}$ test was performed between it and the homogeneous job measure used in the present study. Results are reported in the text.
} 


\section{Control Variables}

Occupational concentration. Because I wish to distinguish ethnic concentration on the job from local ethnic concentration within occupational groupings, I include a control variable that measures the local percentage of coethnics employed in each respondent's respective occupational grouping. To construct this variable, I borrow from recent research by Logan, Alba, and McNulty (1994) and Model (1997), who use data from the 5-Percent Public Use Micro Samples (PUMS) of the population census to subdivide metro economies into 48 industrial sectors (see footnote 1). For the present study, I use the 1990 5-Percent PUMS to subdivide each metro economy in the sample-Atlanta, Boston, and Los Angeles-into 42 occupational groupings based largely on two-digit Census Occupation Codes (see Appendix A for categories and codes). I then calculate each ethnic group's local share of non-self-employed workers in each occupational grouping. For example, if Whites comprise 91\% of Boston's executives (which they do), all White respondents in Boston working in this occupational grouping would receive a value of 0.91. Likewise Black respondents in Boston working in this occupational grouping would receive a value of 0.04 , reflecting their local share of executives.

This measure of occupational concentration is useful in two respects. First, it provides a backdrop against which to assess relative levels of employment in ethnically homogeneous jobs. Second, it serves as an important control variable in multivariate analyses predicting employment in a homogeneous job. Without this control variable, it would be difficult to assess the extent to which covariates were correlated with employment in an ethnically homogeneous job, as opposed to an ethnically concentrated occupation.

Human capital characteristics. Consistent with prior research on ethnic differences in informal job matching and ethnic concentration, I include a measure of education. This variable is operationalized as a continuous measure of years of schooling completed by the respondent. The expectation is that there is an interaction effect with race when it comes to predicting employment in ethnically homogeneous jobs: among minorities, more schooling is likely to lower the odds of working in homogeneous jobs; among Whites, the opposite is true. This interaction effect reflects the differential educational distributions of Whites and non-Whites in the United States.

Because language skills are also likely to affect job matching and ethnic clustering, I control for them as well. This variable is operationalized as three dummy variables corresponding to the following (self-reported) categories: no English ability; little to fair ability; good to very good ability. All native-born respondents fall in the latter category - good to very good-by design. The expectation among foreign-born respondents is that English ability is negatively correlated with employment in homogeneous job-the worse one's English, the greater one's odds of working in a homogeneous job.

Demographic characteristics. To determine whether network hiring and em- 
ployment in homogeneous jobs differ for men and women, I also include a dummy indicator for gender. The measure takes the value of 1 for women and 0 for men. I also include a series of dummy variables for city of residenceAtlanta, Boston, or Los Angeles-to identify and control for geographic differences in job matching and ethnic homogeneity.

Workplace attributes. Although the MCSUI household survey contains relatively few data on workplace attributes, it does have information on two key organizational variables widely suspected of affecting job matching and ethnic composition. The first of these is establishment size. While larger establishments are generally expected to have more formal recruitment procedures (i.e., less informal matching), the effect of establishment size on homogeneous jobs is more ambiguous. On the one hand, smaller establishments are likely to have smaller work groups, which are more easily dominated by a particular race or ethnic group; on the other hand, larger organizations may bring with them greater amounts of sex and race segregation on the job (Bielby and Baron, 1986) and be in a better position to absorb the financial cost of racial discrimination (Tolbert, 1986). I use a logarithmic transformation (natural log) of establishment sizemeasured as the number of employees-with the expectation that the effect of establishment size on working in a homogeneous job is nonlinear (Mueller, Finley, Iverson, and Price, 1999).

The second organizational variable is whether the employer is in the public sector - a bastion of employment opportunities for urban minorities, particularly Blacks (Fernandez, 1975; Reskin and Roos, 1992; Valenzuela, 1998). To account for the unique salience of public sector employment for urban Blacks, I include not only a dummy variable for location in the public sector but also an interaction term for being Black and employed in the public sector. The expectation is that Blacks are more likely than other groups to work in homogeneous jobs within the public sector, where affirmative action on their behalf has been most aggressively pursued.

Having discussed the data and measures used in this research, I now turn to the analyses, beginning with descriptive statistics on ethnic concentration in the labor market.

\section{RESULTS}

Table 1 reports descriptive statistics for several measures of ethnic concentration in the labor market. As a point of departure, it is useful to begin with the mean percentage of coethnics in each respondent's local occupational grouping. Unsurprisingly, native-born Whites have the highest level of occupational concentration at $66.8 \%$. This number means that the average native-born White in the sample works in an occupation that is two thirds White. Recent and established Latino immigrants have the next highest rates of occupational concentration- 45.5 and $38.3 \%$, respectively-compared with $20.7 \%$ among native-born Blacks and $16.9 \%$ among native-born Latinos. 
TABLE 1

Ethnic Occupational Concentration, Homogeneous Jobs, and Job Matching among Recent Hires

\begin{tabular}{|c|c|c|c|c|c|c|}
\hline & $\begin{array}{l}\text { Native-born } \\
\text { Whites }\end{array}$ & $\begin{array}{l}\text { Native-born } \\
\text { Blacks }\end{array}$ & $\begin{array}{l}\text { Native-born } \\
\text { Latinos }\end{array}$ & $\begin{array}{l}\text { Established } \\
\text { Latino } \\
\text { immigrants } \\
(6+\text { years } \\
\text { in U.S. })\end{array}$ & $\begin{array}{c}\text { Recent } \\
\text { Latino } \\
\text { immigrants } \\
\text { (0-5 years } \\
\text { in U.S.) }\end{array}$ & $\begin{array}{c}\chi^{2} \\
(d f, 4)\end{array}$ \\
\hline$N$ & 607 & 707 & 168 & 426 & 122 & \\
\hline $\begin{array}{l}\text { Mean local } \% \text { of coethnics } \\
\text { in occupational } \\
\text { grouping }\end{array}$ & 66.8 & 20.7 & 16.9 & 38.3 & 45.5 & \\
\hline $\begin{array}{l}\text { Percentage employed in a } \\
\text { homogeneous job }\end{array}$ & 76.4 & 49.7 & 42.3 & 70.9 & 90.1 & $185.8 * * *$ \\
\hline Percentage hired formally & 48.9 & 44.7 & 38.1 & 27.2 & 18.9 & $78.4 * * *$ \\
\hline $\begin{array}{l}\text { Percentage hired through } \\
\text { insider referral }\end{array}$ & 26.5 & 29.1 & 38.7 & 42.0 & 53.2 & $56.8 * * *$ \\
\hline $\begin{array}{l}\text { Percentage hired through } \\
\text { other informal channel }\end{array}$ & 24.6 & 26.2 & 23.2 & 30.8 & 27.9 & 6.2 \\
\hline $\begin{array}{l}\text { Percentage of formal hires } \\
\text { leading to homogeneous } \\
\text { jobs }\end{array}$ & $\begin{array}{c}76.4 \\
(n=297)\end{array}$ & $\begin{array}{c}41.1 \\
(n=316)\end{array}$ & $\begin{array}{c}39.1 \\
(n=64)\end{array}$ & $\begin{array}{c}65.5 \\
(n=116)\end{array}$ & $\begin{array}{c}95.7 \\
(n=23)\end{array}$ & $104.2 * * *$ \\
\hline $\begin{array}{l}\text { Percentage of insider } \\
\text { referrals leading to } \\
\text { homogeneous jobs }\end{array}$ & $\begin{array}{c}75.8 \\
(n=161)\end{array}$ & $\begin{array}{c}56.8 \\
(n=378)\end{array}$ & $\begin{array}{c}47.7 \\
(n=65)\end{array}$ & $\begin{array}{c}77.1 \\
(n=179)\end{array}$ & $\begin{array}{c}89.2 \\
(n=65)\end{array}$ & $49.5 * * *$ \\
\hline $\begin{array}{l}\text { Percentage of other } \\
\text { informal channels } \\
\text { leading to homogeneous } \\
\text { jobs }\end{array}$ & $\begin{array}{c}77.2 \\
(n=149)\end{array}$ & $\begin{array}{c}56.2 \\
(n=185)\end{array}$ & $\begin{array}{c}38.5 \\
(n=39)\end{array}$ & $\begin{array}{c}67.2 \\
(n=131)\end{array}$ & $\begin{array}{c}91.8 \\
(n=34)\end{array}$ & $38.8^{* * * *}$ \\
\hline
\end{tabular}

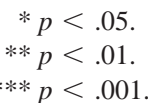

Against these rates of occupational concentration, employment in ethnically homogeneous jobs appears relatively high for all groups. For example, although native-born Blacks work in occupations that, on average, are only $21 \%$ Black, nearly half $(49.7 \%)$ work in predominantly Black, or homogeneous, jobs. The same pattern holds for native-born Latinos: while on average they comprise only $17 \%$ of their local occupational grouping, $42.3 \%$ work in homogeneous jobs. The highest rate of employment in homogeneous jobs, as hypothesized, is among recent Latino immigrants, over $90 \%$ of whom work in ethnically homogeneous jobs (!). Established Latino immigrants are the second highest group at $71 \%$. A $\chi^{2}$ test reported in the right-most column of Table 1 indicates that this group variation in homogeneous jobs is statistically significant at the .001 level.

These preliminary findings are important for a couple reasons. First, they validate the idea that ethnic divisions of labor are more pronounced on the job-that is, within establishments-than within local occupational groupings-a finding which is consistent with well-established patterns of sex segregation in the labor market (Bielby and Baron, 1986; Blau, 1975; Reskin and Roos, 1990; Tomaskovic-Devey, 1993, pp. 24-37). Second, they lend weight to 
the suspicion that native-born Latinos are more similar to native-born Blacks with respect to working in ethnically homogeneous jobs than they are to their foreign-born counterparts. To refine our sense of whether time in the United States affects the likelihood that Latino immigrants enter homogeneous jobs, I estimated a simple logit model with time in the United States as the (continuous) independent variable and employment in a homogeneous job (1, yes; 0 , no) as the dependent variable.

Results (not shown) confirm a significant correlation between the two variables $(P<.001)$ and indicate that with each year in the United States, a Latino immigrant's likelihood of entering a homogeneous job decreases by roughly 2 percentage points - from a estimated $96 \%$ during the first year of settlement (!) to $76 \%$ after 10 years in the United States. This basic pattern is confirmed by a more flexible functional form of the same logit model that uses dummy indicators for various lengths of time in the United States. ${ }^{2}$ If conventional wisdom is correct, this relationship derives, at least in part, from the fact that newly settled immigrants are more likely than other groups to find jobs through informal channels, especially insider referrals.

Descriptive statistics on job matching in the middle of Table 1 support and clarify this conventional wisdom. First, they confirm that recent Latino immigrants-those in the United States for fewer than 5 years-are more likely than other groups to enter jobs with the help of personal contacts (81.1\%). By comparison, the rate among more established Latino immigrants is $72.8 \%$, and among native-born minorities the average is $57.3 \%$. Again, a $\chi^{2}$ test indicates that these group differences are statistically significant at the .001 level and, importantly for this research, that these differences derive almost entirely from group variation in the use of insider referrals, not from other types of informal hiring. This finding supports Hypothesis 1, as does the fact that the majority of informal job matches are insider referrals.

\section{Multivariate Analyses}

To test group differences in job matching more formally, I estimated two multinomial models with the three categories of job matching as the dependent variable. The first model establishes baseline coefficients for each group; the second model adds control variables for personal and workplace characteristics to determine the extent to which these factors explain observed differences in

\footnotetext{
${ }^{2}$ In the more flexible functional form, I substituted a series of nine dummy variables for the continuous measure of years of residence in the United States $(0-2$ years, 3-4, 5-6, 7-8, 9-10, $11-15,16-20,21-30,31+)$. Results of this more flexible functional form are very similar to those reported for the original continuous measure. They show that $93 \%$ of immigrants in the country $0-2$ years $(n=27)$ work in homogeneous jobs and that $79 \%$ of those in the country $9-10$ years $(n=53)$ work in homogeneous jobs. A significant qualitative change in this roughly two-point-per-year decline does not occur until 21-30 years in the United States, during which time 47\% of immigrants work in a homogeneous job, compared with $77 \%$ of those in the United States 16-20 years.
} 
TABLE 2

Multinomial Regression Results Predicting Group Differences in Job Matching (Standard Errors in Parentheses)

\begin{tabular}{|c|c|c|c|c|}
\hline & \multicolumn{2}{|c|}{$\begin{array}{l}\text { Insider referral vs. } \\
\text { formal channel }\end{array}$} & \multicolumn{2}{|c|}{$\begin{array}{l}\text { Other informal vs. } \\
\text { formal channel }\end{array}$} \\
\hline & Model 1 & Model 2 & Model 1 & Model 2 \\
\hline \multirow[t]{2}{*}{ Native-born Black } & .184 & .187 & .154 & .044 \\
\hline & $(.133)$ & $(.138)$ & $(.137)$ & $(.142)$ \\
\hline \multirow[t]{2}{*}{ Native-born Latino } & $.627^{* *} *$ & $.595 * *$ & .194 & .158 \\
\hline & $(.201)$ & $(.210)$ & $(.227)$ & $(.236)$ \\
\hline \multirow[t]{2}{*}{ Established Latino immigrant } & $1.046^{* * * *}$ & $.474 *$ & $.811^{* * *}$ & .166 \\
\hline & $(.154)$ & $(.221)$ & $(.162)$ & $(.246)$ \\
\hline \multirow[t]{2}{*}{ Recent Latino immigrant } & $1.651 * * *$ & $.837 *$ & $1.081 * * *$ & .235 \\
\hline & $(.262)$ & $(.333)$ & $(.288)$ & $(.370)$ \\
\hline Native-born White (reference) & - & - & - & - \\
\hline \multirow[t]{2}{*}{ Female } & & $-0.223^{*}$ & & .037 \\
\hline & & $(.110)$ & & $(.118)$ \\
\hline \multirow[t]{2}{*}{ Years of schooling } & & -0.015 & & -0.044 \\
\hline & & $(.022)$ & & $(.023)$ \\
\hline \multirow[t]{2}{*}{ No English ability } & & $.964 *$ & & .659 \\
\hline & & $(.386)$ & & $(.423)$ \\
\hline \multirow[t]{2}{*}{ Fair English ability } & & $.715 * *$ & & $.807 * *$ \\
\hline & & $(.242)$ & & $(.268)$ \\
\hline Good English ability (reference) & & - & & - \\
\hline \multirow[t]{2}{*}{ Public sector employer } & & -0.098 & & .173 \\
\hline & & $(.161)$ & & $(.163)$ \\
\hline \multirow[t]{2}{*}{ Ln (establishment size) } & & $-0.061^{*}$ & & $-0.063^{*}$ \\
\hline & & $(.031)$ & & $(.032)$ \\
\hline \multirow[t]{2}{*}{ Atlanta } & & .029 & & .222 \\
\hline & & $(.144)$ & & $(.147)$ \\
\hline \multirow[t]{2}{*}{ Boston } & & $-2.58^{*}$ & & $-4.23^{* *}$ \\
\hline & & $(.131)$ & & $(.143)$ \\
\hline Los Angeles (reference) & & - & & - \\
\hline \multirow[t]{2}{*}{ Constant } & $-.612^{* * *}$ & .044 & $-.690 * * *$ & .173 \\
\hline & $(.098)$ & $(.343)$ & $(.100)$ & $(.361)$ \\
\hline$N$ & & & 2,030 & 2,030 \\
\hline$\chi^{2}$ & & & $91.8(8)$ & $146.8(24)$ \\
\hline
\end{tabular}

\footnotetext{
$* p<.05$.

$* * p<.01$.

$* * * p<.001$
}

Model 1. The results appear in Table 2 and affirm that group differences in the use of insider referrals are larger and more robust than group differences in other types of informal job matching.

Regarding Hypothesis 2-that insider referrals vary by immigrant statusonly the reduced Model 1 provides unconditional support. Specifically, $\chi^{2}$ tests of respective coefficients reveal that recent Latino immigrants are significantly 
more likely than established Latino immigrants to acquire jobs through insider referrals $(P=.025)$, who in turn are significantly more likely than native-born Latinos to acquire jobs through insider referrals $(P=.049)$. However, once control variables are entered into Model 2, these significant "immigrant effects" disappear-that is, $\chi^{2}$ tests indicate no statistically significant difference in the use of insider referrals between native-born Latinos and recent or established Latino immigrants.

The implication of these findings is not so much that immigrant status is irrelevant for understanding group differences in insider referrals, but that other factors help to explain why immigrant status matters. A closer look at Model 2 suggests that the most important mediating factor is English ability. As one would expect, weak English skills strongly predict the use of insider referrals among Latino immigrants. Another key factor is the size of the employing establishment. Results show that smaller workplaces are more likely to hire workers through insider referrals, and side analyses confirm that immigrants are more likely than native-born workers to gain employment in smaller workplaces. ${ }^{3}$

Finally, results in Model 2 show that roughly $33 \%$ of men entered jobs through insider referrals, all else equal, compared with $27 \%$ of women. While statistically significant, this six-point difference pales in comparison to the estimated twofold differential between native-born Whites and recent Latino immigrants-26\% compared with $53 \%$, all else equal.

In sum, evidence thus far supports the unique salience of insider referrals for understanding group differences in the job distribution process. It also supports the idea that Latinos, especially recent immigrants, are more reliant on insider referrals than other groups, even after controlling for personal and workplace characteristics. The next question is whether insider referrals significantly increase the likelihood of entering ethnically homogeneous jobs.

By way of background, it is first useful to examine the degree of ethnic homogeneity among referrer-referral pairs - that is, workers and their contactssince a key assumption is that employment networks are ethnically bounded. Here data show that $80 \%$ of insider referrals involve coethnic pairs, compared with $84 \%$ of other types of informal job matches. The magnitude and similarity of these percentages make two important points. First, the use of personal contacts to obtain jobs conforms to assumptions of social homophily-the overwhelming majority of job contacts are the same race and ethnicity as the workers they assist. Second, this ethnic "boundedness" holds whether contacts are insider referrers or not. So any difference in the propensity of insider and outsider contacts to lead to ethnically homogeneous jobs must be explained by

${ }^{3}$ The median number of co-workers among immigrants is 29 , compared with 50 among nativeborn workers. A $t$ test of subsample means confirms a statistically significant difference at the $p<$ .0001 level. 
TABLE 3

Logit Results Predicting Employment in an Ethnically Homogeneous Job

\begin{tabular}{lccc}
\hline & Coefficients & SE & Odds ratios \\
\hline Insider referral & $.283^{*}$ & .125 & 1.32 \\
Other informal match & .086 & .130 & 1.08 \\
Formal job match (reference) & - & - & - \\
Native-born Black & $2.208^{* * *}$ & .673 & 9.09 \\
Native-born Latino & $2.006^{* *}$ & .685 & 7.43 \\
Established Latino immigrant & $2.021^{* *}$ & .684 & 7.54 \\
Recent Latino immigrant & $3.078^{* * *}$ & .772 & 21.71 \\
Native-born White (reference) & - & - & - \\
Female & .149 & .108 & 1.16 \\
Years of schooling & $.111^{* * *}$ & .042 & 1.11 \\
No English ability & $1.671^{* *}$ & .541 & 5.31 \\
Fair English ability & $1.004^{* *}$ & .237 & 2.72 \\
Good English ability (reference) & - & - & - \\
Public sector employer & -0.382 & .212 & 0.68 \\
Ln(establishment size) & $-0.167^{* * *}$ & .029 & 1.181 \\
Atlanta & .032 & .141 & 1.03 \\
Boston & $-0.402^{* * *}$ & .130 & 1.49 \\
Los Angeles (reference) & - & - & - \\
Local \% of coethnics in occupational grouping & $2.401^{* * *}$ & .314 & 11.03 \\
Non-White $\times$ years of schooling & $-0.189^{* * *}$ & .050 & 1.20 \\
Public sector employment $\times$ Black & $.827^{* *}$ & .289 & 2.28 \\
Constant & $-1.243^{*}$ & .608 & \\
$N$ & 2,030 & & \\
$\chi^{2}(d f)$ & $447.0(17)$ & & \\
\hline
\end{tabular}

$$
\begin{aligned}
* p & <.05 . \\
* * p & <.01 . \\
* * * & <.001 .
\end{aligned}
$$

something other than differences in the likelihood that one or the other type of job contact is coethnic.

With these points in mind, I fit a logistic regression model predicting employment in an ethnically homogeneous job (1, yes; 0, no). On the right-hand side of the equation, I include group indicators and the same control variables as those in Table 2. I also add several new control variables that I discussed above. First, I include the percentage of coethnics in each respondent's local occupational grouping to control for racial and ethnic concentration within occupations, which affects, but is conceptually distinct from, job-level concentration. I also include two interaction terms: one distinguishes the effects of schooling for Whites and non-Whites; the other distinguishes the effects of public sector employment for Blacks and non-Blacks. The results appear in Table 3.

The first question is whether insider referrals are more likely than other modes of job matching to lead to ethnically homogeneous jobs, net of the control factors. The answer, as hypothesized, is yes. Results show that the odds of 
entering homogeneous jobs increase an average of 1.32 times when workers use insider referrals compared with formal recruitment channels. There is no significant increase in the likelihood of entering homogeneous jobs when other types of job contacts are used. In other words, it is insider referrals in particular that lead disproportionately to ethnically homogeneous jobs, not job contacts in general. Again, this is true despite the fact that almost all job contacts are coethnic, whether they are insiders or not.

Further examination of Table 3 shows that the use of insider referrals, while statistically significant, does not fully explain group differences in the propensity to enter ethnically homogeneous jobs. In fact, net of other factors, the odds that a recent Latino immigrant will enter a homogeneous job are over 20 times greater than those of a native-born White and 2.3 times greater than those of a nativeborn Black. It is important to note, however, that these statistically significant differences emerge only after the interaction term for non-Whites and years of schooling is entered into the model-without this interaction term, group differences are statistically insignificant. ${ }^{4}$

To help clarify the relationship between educational achievement and homogeneous jobs, Fig. 1 reports the estimated percentages of each group in homogeneous jobs by the highest educational degree earned. These results are calculated from a logit model similar to that reported in Table 3, but which measures educational achievement as a series of dummy variables and interacts them with each of the five groups of interest (logit results not shown). To control for compositional differences among respective groups, I set the values of all nondisplayed variables to their grand population means. Thus differences illustrated in Fig. 1 reflect group differences in effect, net of group differences in composition. The main conclusion from Fig. 1, echoing Table 3, is that as racial and ethnic minorities become more educated, they become less likely to enter homogeneous jobs, while the opposite is true for native-born Whites. The most notable effect occurs among native-born Latinos, whose likelihood of working in homogeneous jobs plunges from roughly $60 \%$ among high school and community college graduates to less than $20 \%$ among those with a Bachelor's degree. By comparison, roughly $60 \%$ of Blacks with a Bachelor's degree work in homogeneous jobs, net of other factors.

In addition to educational attainment, the other interaction term in Table 3-distinguishing Blacks and non-Blacks in the public sector-is also statistically significant in the expected direction. Results indicate that native-born Blacks are over twice as likely to work in homogeneous jobs when they are employed in the public sector as opposed to the private sector. Additional analyses with separate interaction terms for each group (not shown) reveal that native-born Blacks are the only group to experience this statistically significant

\footnotetext{
${ }^{4}$ Supplemental analyses with a full set of ethnic/immigrant interaction terms (not shown) indicate no statistically significant differences among respective non-White groups at the .05 level. Thus, I simplify the analysis by creating a single interaction term for Whites and non-Whites.
} 


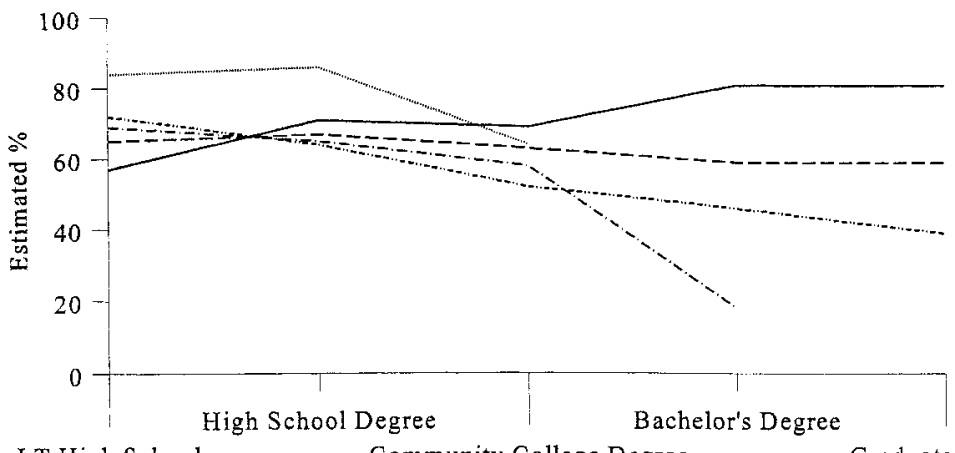

LT High School

Community College Degree

Graduate Degree

FIG. 1. Simulated percentages of employees in homogeneous jobs by group: (-) native-born Whites; (- - ) native-born Blacks; (- - ) native-born Latinos; (- - . ) established Latino immigrants; $(\cdots)$ recent Latino immigrants. (Source) A more flexible functional form of the logit model presented in Table 3 that uses dummy variables (rather than years of education) for educational achievement and interacts them with dummy variables for each group. (Notes) Estimated percentages are calculated by holding all other variables in the equation at their grand population means. Thus graph lines reflect group differences, net of compositional differences among groups. Graph lines are incomplete for established and recent Latino immigrants because of the insufficient cases at higher levels of educational attainment.

effect. (Gender plays no significant role in predicting ethnically homogeneous jobs, net of other factors.)

As the final step in my multivariate analysis, I wished to determine if the link between insider referrals and homogeneous jobs is stronger for some groups than others. One expectation is that immigrants will experience a tighter and more statistically significant link than native-born minorities, particularly Blacks, because of their unique reliance on social networks in the labor market. To test this idea I reestimated the model in Table 3 but this time included interaction terms for each group by type of job matching (e.g., native-born Black by insider referral; native-born Black by other type of informal job matching; and so forth). The results appear in Table 4, and a $\chi^{2}$ test of model significance indicates that it provides a better fit than the simpler model reported in Table 3 (16.4 @ $8 d f$; $p<.05)$. For presentation purposes I report only coefficients for the main and interaction effects of interest. (Patterns for the control variables remain essentially unchanged from those reported in Table 3).

In short, results run counter to expectation, showing that the link between insider referrals and homogeneous jobs is statistically significant only for nativeborn Blacks. Specifically, net of other factors, native-born Blacks who use insider referrals are twice as likely to enter homogeneous jobs as native-born Blacks who enter jobs through formal channels. At first this finding might seem paradoxical: How could the group with the lowest level of insider referrals and homogeneous employment experience the strongest relative link between the two? A look back to the bottom Table 1 offers an explanation. Descriptive statistics show that 
TABLE 4

Abridged Logit Results with Interaction Terms Predicting Employment in an Ethnically Homogeneous Job

\begin{tabular}{lccc}
\hline & Coefficients & SE & Odds ratios \\
\hline Insider referral & -0.101 & .238 & 0.90 \\
Other informal match & .118 & .248 & 1.12 \\
Formal job match (reference) & - & - & - \\
Native-born Black & $1.944^{* *}$ & .695 & 6.98 \\
Native-born Latino & $2.019^{* *}$ & .731 & 7.530 \\
Established Latino immigrant & $2.126^{* *}$ & .721 & 8.38 \\
Recent Latino immigrant & $4.249^{* *}$ & 1.270 & 70.03 \\
Native-born White (reference) & - & - & - \\
Native Black $\times$ Insider referral & $.673^{*}$ & .304 & 1.96 \\
Native Black $\times$ Other informal match & .301 & .317 & 1.35 \\
Native Latino $\times$ Insider referral & .304 & .450 & 1.35 \\
Native Latino $\times$ Other informal match & -0.369 & .511 & 0.69 \\
Estab'd Latino immigrant $\times$ Insider referral & .271 & .394 & 1.31 \\
Estab'd Latino immigrant $\times$ Other informal match & -0.721 & .413 & 0.48 \\
Recent Latino immigrant $\times$ Insider referral & -1.495 & 1.173 & 0.22 \\
Recent Latino immigrant $\times$ Other informal match & -1.209 & 1.270 & 0.29 \\
$N$ & 2,030 & & \\
$\chi^{2}$ & $463.4(25)$ & & \\
\hline
\end{tabular}

Note. Control variables estimated in this model but not reported include the following: local percentage of coethnics within the respondent's occupational grouping; female; years of schooling; English ability (none; fair; good); public sector employment; natural log of establishment size; city of residence (Atlanta; Boston; Los Angeles); an interaction term for non-White by years of schooling; and an interaction term for Black by public sector employment.

$$
\begin{gathered}
* p<.05 . \\
* * p<.01 . \\
* * * p<.001 .
\end{gathered}
$$

although foreign- and native-born Latinos have higher rates of insider referrals and employment in homogeneous jobs, native-born Blacks rely more heavily on insider referrals, relative to formal channels, to enter and thus sustain homogeneous jobs. Among Latino immigrants, by contrast, nearly all workers enter homogeneous jobs, regardless of the mode in which they are hired. The same is true of native-born Whites.

To determine if this singularly significant effect for Blacks is an artifact of differential human capital distributions among groups, I reran the model in Table 4 for respondents with no more than 12 years of schooling (not shown). The logic is that ethnic competition is fiercest among less educated workers because there are fewer educational credentials to legitimate group differences. The same pattern from Table 4 emerges: only the Black interaction term with insider referrals is statistically significant at the .05 level. Finally, I ran a main effects model separately for native-born Blacks in three educational categories: those with less than a high school degree; those with a high school degree; and those 
with some college. Results in all three models show a statistically significant correlation between insider referrals and homogeneous jobs. In short, the significant correlation identified in Table 4 is robust for native-born Blacks at all levels of education.

\section{SUMMARY AND CONCLUSION}

By way of summary, I return to the three hypotheses posed earlier. First, survey data confirm that insider referrals play a critical role in understanding contemporary job matching, that is, how jobs get distributed. Overall, insider referrals accounted for a third of all new hires in Atlanta, Boston, and Los Angeles during the early 1990s - the majority of all informal hires (55\%), including nonsearch matches.

Second, evidence shows that the likelihood of insider referrals varies significantly by immigrant status but that this difference is largely explained by limited English ability and the propensity to gain employment in relatively small workplaces, both of which increase workers' odds of entering jobs through referral hiring. Once these factors are controlled, ethnicity, rather immigrant status, becomes more important in predicting insider referrals. Specifically, results show that Latinos are more likely than native-born Whites to gain employment through insider referrals, all else equal-a finding that is consistent with those of prior research (Falcon and Melendez, 1996; Green, Tigges, and Diaz, 1999). Results also indicate that there is no significant difference between native-born Blacks and Latinos with respect to using insider referrals to acquire jobs, net of other factors.

Third and finally, results confirm the widely held belief that, in general, workers who acquire jobs through insider referrals are significantly more likely than other types of workers to enter, and thus help to sustain, ethnically homogeneous jobs. Perhaps most surprising, however, is the finding that this relationship holds only for native-born Blacks and is statistically insignificant for other groups, including immigrant Latinos. While informative, this finding should not be construed to imply that insider referrals are unimportant for understanding the ethnic concentration of immigrants within and across workplaces. In fact, evidence from the MCSUI shows that $36 \%$ of recent Latino immigrants who entered jobs during the early 1990s did so with the help of insiders who matched them to ethnically homogeneous jobs-double the percentage among native-born Latinos $(18 \%)$ and native-born Blacks $(16 \%)$. The reason then for the noncorrelation between insider referrals and homogeneous jobs among recent Latino immigrants is simply that group members are highly likely to enter homogeneous jobs regardless of how they acquire their jobs (90\%) — there is little variation in the dependent variable.

Among native-born Blacks, one explanation for the surprisingly strong link between insider referrals and homogeneous jobs might lie with well-documented patterns of employer discrimination against Blacks in the hiring process 
(Kirschenman and Neckermann, 1991; Moss and Tilly, 1996; Waldinger, 1997; Wilson, 1996). Such an explanation might run as follows. Because employers tend to place Blacks at the end of the hiring queue, it is difficult for Blacks to establish themselves as a majority on the job. The logic of queuing theory suggests that such cases will occur only in situations where workers from other racial and ethnic groups do not compete for the jobs in question. This lack of ethnic competition can arise when jobs are particularly unattractive or when they are in the public sector, where discrimination against Blacks is lower and commitment to affirmative action higher. A lack of ethnic competition can also arise, as this research has emphasized, in jobs filled through insider referrals. So one reason insider referrals might be more likely than formal recruitment channels to match Blacks to homogeneous jobs is because without the restricted access implied by insider referrals, White and Latino workers would be more likely to learn about, acquire, and dominate the jobs in question. Relatedly, insider referrals might also be important for convincing employers, even Black employers (Wilson, 1996), that a predominantly Black workforce is acceptable.

Of course this line of thinking is more complex than it might first appear. The reason is that an employer's predisposition to hire through insider referrals reflects its predisposition toward the demographic composition of its existing workforce, which in turn reflects organizational prerogatives set in motion long before current applicants for new job openings are screened and hired. But this logic brings us back to the original point-insider referrals tend to reproduce the ascriptive characteristics of incumbent workers, thereby helping to maintain ethnic segregation on the job over time. What makes native-born Blacks unique is that insider referrals are especially important for establishing and sustaining "Black" jobs because formal channels are unlikely to do so. Among other race and ethnic groups (who are less likely to be discriminated against in the hiring process) all types of job matching, including formal channels, are equally likely to lead to ethnically homogeneous jobs.

Finally, with respect to immigrant Latinos, although there is no evidence of a significant correlation between insider referrals and employment in ethnically homogeneous jobs, there might be an important feedback mechanism missed by the MCSUI data. It is quite possible that insider referrals that help many immigrant Latinos circumvent English deficiencies and enter ethnically homogeneous jobs also work to inhibit job mobility into non-homogeneous jobs in the future. The assumption here is that jobs that are mostly Latino might retard exposure to and incentive to learn English, thereby minimizing future job opportunities that require solid English skills, even those that might be filled through formal channels. Although the MCSUI does not have data on the language spoken on the job, indirect evidence supports this possibility. It shows that among established Latino immigrants, workers in ethnically homogeneous jobs are significantly more likely than workers in non-homogeneous jobs to report little to no English ability, despite at least 5 years in the country. This pattern reminds us that ethnic divisions of labor within urban economies are 
sustained by language barriers, in addition to insider referrals, and that the two mechanisms likely intertwine to shape not only individual life chances but also the ethnic contours of today's urban labor markets.

\section{APPENDIX A: Occupational Groupings with Their 1990 Census Occupation Codes}

\begin{tabular}{|c|c|c|c|}
\hline Occupational groupings & $\begin{array}{l}\text { Census } \\
\text { occupation } \\
\text { codes }\end{array}$ & Occupational groupings & $\begin{array}{l}\text { Census } \\
\text { occupation } \\
\text { codes }\end{array}$ \\
\hline Executives and administrators & $1-22$ & Private household occupations & $403-412$ \\
\hline Managers & $23-42$ & Protective services & $413-432$ \\
\hline $\begin{array}{l}\text { Engineers, architects, and } \\
\text { surveyors }\end{array}$ & $43-63$ & Food preparation and service & $433-444$ \\
\hline $\begin{array}{l}\text { Mathematical and computer } \\
\text { scientists }\end{array}$ & $64-68$ & Health services & $445-447$ \\
\hline Natural scientists & $69-83$ & $\begin{array}{l}\text { Cleaning and building services } \\
\text { (except households) }\end{array}$ & $448-455$ \\
\hline Health diagnosing occupations & $84-94$ & Personal services & $456-472$ \\
\hline $\begin{array}{l}\text { Health assessment and treating } \\
\text { occupations }\end{array}$ & $95-112$ & $\begin{array}{l}\text { Farm operators and managers, other } \\
\text { agricultural occupations, forestry, } \\
\text { logging, fishers, hunters, and } \\
\text { trappers }\end{array}$ & $473-502$ \\
\hline Postsecondary teachers & $113-154$ & Mechanics and repairers & $503-552$ \\
\hline $\begin{array}{l}\text { Teachers (except postsecondary) } \\
\text { and educational and } \\
\text { vocational counselors }\end{array}$ & $155-165$ & Construction trades & $553-612$ \\
\hline $\begin{array}{l}\text { Social scientists, urban planners, } \\
\text { and social, recreation, and } \\
\text { religious workers }\end{array}$ & $166-182$ & Extractive occupations & $613-627$ \\
\hline $\begin{array}{l}\text { Writers, artists, entertainers, and } \\
\text { athletes }\end{array}$ & $183-202$ & Precision production occupations & $628-702$ \\
\hline $\begin{array}{l}\text { Health technologists and related } \\
\text { support occupations }\end{array}$ & $203-212$ & $\begin{array}{l}\text { Metal working and plastic working; } \\
\text { processing machine operators }\end{array}$ & $703-725$ \\
\hline $\begin{array}{l}\text { Other technologists and } \\
\text { technicians }\end{array}$ & $213-242$ & Woodworking machine operators & $726-733$ \\
\hline $\begin{array}{l}\text { Sales supervisors and } \\
\text { proprietors, and sales } \\
\text { representatives (except retail) }\end{array}$ & $243-262$ & Printing machine operators & $734-737$ \\
\hline $\begin{array}{l}\text { Sales workers, retail and } \\
\text { personal services, and sales- } \\
\text { related occupations }\end{array}$ & $263-302$ & $\begin{array}{l}\text { Textile, apparel and furnishings } \\
\text { machine operators }\end{array}$ & $738-752$ \\
\hline $\begin{array}{l}\text { Supervisors of administrative } \\
\text { support }\end{array}$ & $303-307$ & $\begin{array}{l}\text { Machine operators, assorted } \\
\text { materials, and otherwise not } \\
\text { specified }\end{array}$ & $753-802$ \\
\hline $\begin{array}{l}\text { Computer operators, secretaries, } \\
\text { and records processing } \\
\text { occupations (except financial) }\end{array}$ & $308-336$ & Motor vehicle operators & $803-822$ \\
\hline $\begin{array}{l}\text { Financial records processing } \\
\text { occupations }\end{array}$ & $337-344$ & Other transportation occupations & $823-842$ \\
\hline
\end{tabular}




\section{APPENDIX A-Continued}

\begin{tabular}{lccc}
\hline & $\begin{array}{c}\text { Census } \\
\text { occupation } \\
\text { codes }\end{array}$ & Occupational groupings & $\begin{array}{c}\text { Census } \\
\text { occupation } \\
\text { codes }\end{array}$ \\
\hline $\begin{array}{c}\text { Duplicating, mail, office } \\
\text { machine operators; } \\
\text { communications equipment } \\
\text { operators, and mail and } \\
\text { message distributing }\end{array}$ & $345-358$ & $\begin{array}{c}\text { Material moving equipment } \\
\text { operators }\end{array}$ & $843-863$ \\
$\begin{array}{l}\text { Material recording, scheduling, } \\
\text { and distributing clerks }\end{array}$ & $359-374$ & $\begin{array}{c}\text { Handlers, equipment cleaners, } \\
\text { helpers and laborers }\end{array}$ & $864-902$ \\
$\begin{array}{c}\text { Adjusters and investigators } \\
\text { Miscellaneous administrative } \\
\text { support occupations }\end{array}$ & $375-378$ & Military [excluded from analysis] & $903-908$ \\
\hline
\end{tabular}

\section{REFERENCES}

Aponte, R. (1996). "Urban employment and the mismatch dilemma: Accounting for the immigration exception," Social Problems 43(3), 268-283.

Bailey, T. R., and Waldinger, R. (1991). "Primary, secondary, and enclave labor markets: A training systems approach," American Sociological Review 56, 432-445.

Bielby, W., and Baron, J. (1986). "Men and women work: Sex segregation and statistical discrimination," American Journal of Sociology 91, 759-799.

Blau, F. (1975). "Sex segregation of workers by enterprise," in Labor Market Segmentation (R. C. Edwards, M. Reich, and D. M. Gordon, Eds.), pp. 257-275, Heath, Lexington, MA.

Bodnar, J., Simon, R., and Weber, M. P. (1982). Lives of Their Own: Blacks, Italians, and Poles in Pittsburgh, 1900-1960, Univ. of Illinois Press, Urbana.

Boyd, M. (1989). "Family and personal networks in international migration: Recent developments and new agendas," International Migration Review 23, 638-670.

Braddock, J. H., II, and McPartland, J. M. (1987). "How minorities continue to be excluded from equal employment opportunities: Research on labor market and institutional barriers," Journal of Social Issues 43(1), 5-39.

Breaugh, J. A., and Mann, R. (1984). "Recruiting source effects: A test of two alternative explanations," Journal of Occupational Psychology 57, 261-267.

Clark, K. (1964). Youth in the Ghetto, Harlem Youth Opportunities Limited, New York.

Cohn, S., and Fossett, M. (1996). "What spatial mismatch?: the proximity of Blacks to employment in Boston and Houston," Social Forces 75(2), 557-572.

Corcoran, M., Datcher, L., and Duncan, G. (1980). "Information and influence networks in labor markets," in Five Thousand American Families: Patterns of Economic Progress, (G. Duncan and J. Morgan, Eds.), Vol. VIII, pp. 1-37. Inst. Social Research, Ann Arbor, MI.

Elliott, J. R. (1999). "Social isolation and labor market insulation: Network and neighborhood effects on less-educated urban workers," The Sociological Quarterly, 40(2), 199-216.

Elliott, J. R. (2000). "Class, race and job matching in urban labor markets," Social Science Quarterly 81(4), 1036-1052.

Falcon, L. M., and Melendez, E. (1996). The Role of Social Networks in the Labor Market Outcomes of Latinos, Blacks and Non-Hispanic Whites. Paper presented at the Russell Sage Foundation Conference on "Residential Segregation, Social Capital and Labor Markets," New York City. Fernandez, J. P. (1975). Black Managers in White Corporations, Wiley, New York.

Fernandez, R., Castilla, E., and Moore, P. (2000). "Social capital at work: Networks and employment at a phone center," American Journal of Sociology 105(5), 1288-1356. 
Fernandez, R., and Weinberg, N. (1997). "Sifting and sorting: Personal contacts and hiring in a retail bank," American Sociological Review 62, 883-902.

Glass, J. (1990). "The impact of occupational segregation on working conditions," Social Forces 68 , 779-796.

Granovetter, M. (1974). Getting a Job: A Study of Contacts and Careers, 1st ed., Univ. of Chicago Press, Chicago.

Granovetter, M. (1995). "Afterword 1994: Reconsiderations and a new agenda," in Getting a Job: A Study of Contacts and Careers, 2nd ed., pp. 139-182, Univ. of Chicago Press, Chicago.

Green, G., Tigges, L., and Diaz, D. (1999). "Racial and ethnic differences in job search strategies in Atlanta, Boston, and Los Angeles," Social Science Quarterly, 80(2), 263-278.

Grieco, M. (1987). Keeping It in the Family: Social Networks and Employment Chance, Tavistock, London.

Hagan, J. M. (1994). Deciding to Be Legal, Temple Univ. Press, Philadelphia.

Hagan, J. M. (1998). "Social networks, gender, and immigrant incorporation: Resources and constraints," American Sociological Review 63, 55-67.

Hareven, T. (1975). "The laborers of Manchester, New Hampshire: The roles of family and ethnicity in adjustment to industrial life," Labor History 16, 249-265.

Holzer, H. J. (1987). "Informal job search and Black youth employment," American Economic Review 77, 446-452.

Holzer, H. J. (1996). What Employers Want: Job Prospects for Less-Educated Workers, Sage, New York.

Johnson, J., Oliver, M., and Bobo, L. (1994). "Unraveling the paradox of deepening urban inequality: Theoretical underpinnings and research design of a multi-city study," Urban Geography 15, 77-89.

Kalleberg, A., Knoke, D., Marsden, P., and Spaeth, J. (1996). Organizations in America: Analyzing Their Structures and Human Resource Practices, Sage, Thousand Oaks, CA.

Kasinitz, P., and Rosenberg, J. (1996). "Missing the connection: Social isolation and employment on the Brooklyn waterfront," Social Problems 43(2), 180-196.

Kirschenman, J., and Neckerman, K. M. (1991). "We'd love to hire them, but . . ': The meaning of race for employers," in The Urban Underclass (C. Jencks and P. Peterson, Eds.), pp. 203-232, Brookings Inst., Washington DC.

Logan, J., Alba, R. D., and McNulty, T. L. (1994). "Ethnic economies in metropolitan regions: Miami and beyond," Social Forces 72, 691-724.

MacDonald, J., and MacDonald, L. (1964). "Chain migration, ethnic neighborhood formation, and social networks," Milbank Memorial Fund Quarterly 52, 82-97.

Massey, D., Alcaron, R., Durand, J., and Gonzalez, H. (1987). Return to Aztalan: The Social Process of Migration from Western Mexico, Univ. of California Press, Berkeley.

Marx, J., and Leicht, K. T. (1992). "Formality of recruitment to 229 jobs: Variations by race, sex, and job characteristics," Social Science Research 76, 190-196.

Mier, R., and Giloth, R. (1985). "Hispanic employment opportunities: A case of internal labor markets and weak-tied social networks," Social Science Quarterly 66, 296-309.

Model, S. (1993). "The ethnic niche and the structure of opportunity: Immigrants and minorities in New York City," in The Underclass Debate: Views from History (M. Katz, Ed.), pp. 161-193, Princeton Univ. Press, Princeton.

Model, S. (1997). "Ethnic economy and industry in mid-twentieth century Gotham," Social Problems 44, 445-463.

Moss, P., and Tilly, C. (1996). "Soft skills and race: An investigation of black men's employment problems," Work and Occupations 23, 252-276.

Mueller, C. W., Finley, A., Iverson, R. D., and Price, J. L. (1999). "The effects of group racial composition on job satisfaction, organizational commitment, and career commitment," Work and Occupations 26, 187-219.

Myers, C. A., and Shultz, G. P. (1951). The Dynamics of a Labor Market, Prentice Hall, New York. 
Nee, V., Sanders, J., and Sernau, S. (1994). "Job transitions in an immigrant metropolis: Ethnic boundaries and the mixed economy," American Sociological Review, 59(6), 849-872.

O'Connor, A., Tilly, C., and Bobo, L. D. (Eds.) (2000). Urban Inequality: Evidence from Four Cities, Sage, New York.

Portes, A., and Bach, R. (1985). Latin Journey: Cuban and Mexican Immigrants in the United States, Univ. of California Press, Berkeley.

Rees, A. (1966). "Information networks in labor markets," American Economic Review 56, 559-566.

Rees, A., and Shultz, G. P. (1970). Workers and Wages in an Urban Labor Market, Chicago Univ. Press, Chicago.

Reichers, A. E. (1987). "An interactionist perspective on newcomer socialization rates," Academy of Management Review 12(2), 278-287.

Reskin, B. F., and Roos, P. (1990). Job Queues, Gender Queues: Explaining Women's Inroads to Male Occupations, Temple Univ. Press, Philadelphia.

Reskin, B. F., McBrier, D. B., and Kmec, J. (1999). "The determinants and consequences of workplace sexual and race composition," Annual Review of Sociology 25, 335-361.

Saloner, G. (1985). "Old boy networks as a screening mechanism," Journal of Labor Economics 3, 255-267.

Sassen, S. (1995). "Immigration and local labor markets," in The Economic Sociology of Immigration (A. Portes, Ed.), pp. 87-127, Sage, New York.

Schwab, D. P. (1982). "Recruiting and organizational participation," in Personnel Management (K. Rowland and G. Ferris, Eds.), pp. 103-127, Allyn \& Bacon, Boston.

Sorenson, E. (1989). "Measuring the effect of occupational sex and race composition on earnings," in Pay Equity: Empirical Inquiries (R. T. Michael, H. I. Hartmann, and B. O'Farrell, Eds.), pp. 49-70, Natl. Acad. Press, Washington, DC.

Sutton, R. I., and Louis, M. R. (1987). "How selecting and socializing newcomers influences insiders," Human Resources Management 26, 347-361.

Tolbert, C. (1986). "Organizations and inequality: Sources of earnings differences between male and female faculty," Sociology of Education 59(4), 227-236.

Tomaskovic-Devey, D. (1993). Gender and Racial Inequality at Work: The Sources and Consequences of Job Segregation, ILR Press, Ithaca.

Ullman, J. C. (1966). "Employee referrals: Prime tool for recruiting workers," Personnel 43, 30-35.

Valenzuela, A. (1998). The Role of Job Search Methods in Public Sector Employment. Paper presented at the Multi-City Survey of Urban Inequality Workshop at ICPSR, University of Michigan, June 15-19.

Waldinger, R. (1996). Still the Promised City? African-Americans and New Immigrants in Postindustrial New York, Harvard Univ. Press, Cambridge, MA.

Waldinger, R. (1997). "Black/immigrant competition re-assessed: New evidence from Los Angeles," Sociological Perspectives 40, 365-386.

Wells, M. J. (1996). Strawberry Fields: Politics, Class and Work in California Agriculture, Cornell Univ. Press, Ithaca, NY.

Wilson, F. D. (2000). Metropolitan Labor Markets and Ethnic Niching: Introduction to a Research Project. Institute for Research on Poverty Discussion Paper 1204-00, Madison, WI.

Wilson, W. J. (1996). When Work Disappears: The World of the New Urban Poor, Knopf, New York. 